\title{
Plasma Lipidome, PNPLA3 polymorphism and hepatic steatosis in hereditary hemochromatosis
}

Jessica Seeßle ${ }^{1}$, Hongying Gan-Schreier ${ }^{1}$, Marietta Kirchner ${ }^{2}$, Wolfgang Stremmel ${ }^{1}$, Walee Chamulitrat ${ }^{1}$ and Uta Merle ${ }^{1 *}$ (iD

\begin{abstract}
Background: Hereditary hemochromatosis $(\mathrm{HH})$ is an autosomal recessive genetic disorder with increased intestinal iron absorption and therefore iron Overload. iron overload leads to increased levels of toxic non-transferrin bound iron which results in oxidative stress and lipid peroxidation. The impact of iron on lipid metabolism is so far not fully understood. The aim of this study was to investigate lipid metabolism including lipoproteins (HDL, LDL), neutral (triglycerides, cholesterol) and polar lipids (sphingo- and phospholipids), and PNPLA3 polymorphism (rs738409//148M) in HH.
\end{abstract}

Methods: We conducted a cohort study of 54 subjects with $\mathrm{HH}$ and 20 healthy subjects. Patients were analyzed for their iron status including iron, ferritin, transferrin and transferrin saturation and serum lipid profile on a routine follow-up examination.

Results: $\mathrm{HH}$ group showed significantly lower serum phosphatidylcholine $(\mathrm{PC})$ and significantly higher phosphatidylethanolamine (PE) compared to healthy control group. The ratio of PC/PE was clearly lower in $\mathrm{HH}$ group indicating a shift from PC to PE. Triglycerides were significantly higher in $\mathrm{HH}$ group. No differences were seen for HDL, LDL and cholesterol. Hepatic steatosis was significantly more frequent in HH. PNPLA3 polymorphism (CC vs. CG/GG) did not reveal any significant correlation with iron and lipid parameters including neutral and polar lipids, grade of steatosis and fibrosis.

Conclusion: Our study strengthens the hypothesis of altered lipid metabolism in $\mathrm{HH}$ and susceptibility to nonalcoholic fatty liver disease. Disturbed phospholipid metabolism may represent an important factor in pathogenesis of hepatic steatosis in $\mathrm{HH}$.

Keywords: Hereditary hemochromatosis, Plasma lipidome, Phospholipids, Triglycerides, Nonalcoholic fatty liver disease, PNPLA3 polymorphism

\footnotetext{
* Correspondence: uta.merle@med.uni-heidelberg.de

'Department of Gastroenterology, University Hospital Heidelberg, Im

Neuenheimer Feld 410, 69120 Heidelberg, Germany

Full list of author information is available at the end of the article
}

(c) The Author(s). 2020 Open Access This article is licensed under a Creative Commons Attribution 4.0 International License, which permits use, sharing, adaptation, distribution and reproduction in any medium or format, as long as you give appropriate credit to the original author(s) and the source, provide a link to the Creative Commons licence, and indicate if changes were made. The images or other third party material in this article are included in the article's Creative Commons licence, unless indicated otherwise in a credit line to the material. If material is not included in the article's Creative Commons licence and your intended use is not permitted by statutory regulation or exceeds the permitted use, you will need to obtain permission directly from the copyright holder. To view a copy of this licence, visit http://creativecommons.org/licenses/by/4.0/. The Creative Commons Public Domain Dedication waiver (http://creativecommons.org/publicdomain/zero/1.0/) applies to the data made available in this article, unless otherwise stated in a credit line to the data. 


\section{Background}

Hereditary hemochromatosis $(\mathrm{HH})$ is an autosomal recessive genetic disorder with increased intestinal iron absorption which leads to iron overload and consequently to tissue damage and functional impairment of organs like liver, pancreas, and heart [1-3]. Iron is an essential metal involved in a wide spectrum of physiological functions such as oxygen transport and enzymatic reactions. Iron overload leads to increased levels of toxic nontransferrin bound iron (NTBI) which results in oxidative stress and lipid peroxidation [3, 4].

Iron overload has a direct effect on hepatic lipid metabolism [5]. Animal models with dietary iron overload showed marked changes in plasma lipid profiles with elevated triglycerides and total cholesterol, decreased high-density lipoprotein (HDL), altered composition of very-low density lipoprotein (VLDL) and hepatic sterol metabolism [6-8]. Iron treated HepG2 cells revealed a decrease of apolipoprotein B100 (ApoB100) and VLDL secretion [9] which was reversed by the iron chelator desferroxamine [10]. Additionally, iron overload increased intracellular lipid droplets, which was associated with increased phosphatidylserine (PS) in the outer leaflet of the plasma membrane [11]. This alteration was also observed in membranes of erythrocytes in $\mathrm{HH}$ [12]. Iron excess induces distinct changes in the serum concentrations of unsaturated long-chain fatty-acyl phosphatidylcholine (PC) including PC 40:2, PC 40:3, PC 40: 4 , and $\mathrm{PC} 42: 1$ in diabetes mellitus type 2 [13]. Inhibition of hepatic PC biosynthesis results in triglyceride accumulation and impairs the secretion of VLDL $[14,15]$. In rat livers excess dietary iron intake causes prosteatotic state which was associated with a decrease in $\omega-3$ long-chain polyunsaturated fatty acid (PUFA) levels and an upregulation of the expression of lipogenic transcription factors [16].

In humans iron overload causes elevated triglycerides [17]. Genetic predisposition for $\mathrm{HH}$ is associated with primary hypertriglyceridemia [18]. Hypertriglyceridemia was found in almost a third of subjects with $\mathrm{HH}$ which was significantly decreased by phlebotomies [19] whereas in non-HH subjects with hyperferritinemia and hypertriglyceridemia repeated phlebotomies did not reduce triglyceride concentrations [20]. Reduced levels of LDL at baseline [10] and an increase of HDL under phlebotomy in $\mathrm{HH}$ patients were shown [21], but in their study no effect of phlebotomy was seen on total cholesterol, low density lipoprotein (LDL) and triglyceride levels [21]. Hence, iron has effects on hepatocellular metabolism of phospholipids and lipoproteins, and on unsaturation of fatty acids in experimental and clinical settings.

Obesity-related steatosis is already identified as cofactor in liver injury in $\mathrm{HH}$ [22], but $\mathrm{HH}$ is also associated with increased susceptibility to nonalcoholic fatty liver disease (NAFLD) despite lower BMI and lower triglycerides levels [23, 24]. Nevertheless the role of HFE polymorphism in the occurrence of NAFLD is not fully understood.

PNPLA3 (human patatin like phospholipase domaincontaining 3) belongs to a group of lipid metabolizing enzymes [25]. In humans, PNPLA3 has the highest expression in the hepatic stellate cells, retina, and hepatocytes [26]. The rs738409 CG variant in PNPLA3 is considered the major genetic determinant of NAFLD [27]. SNPs rs738409 C > G in the PNPLA3 gene encodes for the isoleucine to methionine substitution at position 148 (I148M). It has been shown that PNPLA3 has a triglyceride hydrolase activity [28]. The I148M mutation causes a loss of function of the enzymes activity leading to impairment of lipid catabolism, lipid droplets remodeling, and VLDL secretions in hepatocytes with reduced fatty acid hydrolysis, increased triglyceride accumulation and a decrease of VLDL secretion thereby contributing to hepatic steatosis, inflammation and a greater risk for developing fibrosis [26, 29-32]. These alterations were observed with and without symptoms of metabolic syndrome like insulin resistance and obesity [33, 34]. In $\mathrm{HH}$ the I148M variant was linked with the severity of fibrosis [35]. The mechanism underlying the progression of liver disease is still under investigation. It is hence surmised that the role of iron overload on hepatocellular lipid metabolism may involve PNPLA3.

Therefore, the aim of our study was to evaluate alterations in lipid metabolism including analyses of blood neutral and polar lipids depending on iron status and PNPLA3 polymorphism (rs738409/I148M) in our $\mathrm{HH}$ cohort in comparison to healthy control group.

\section{Methods \\ Study population}

A total of 54 subjects with $\mathrm{HH}$ were retrospectively examined at Internal Medicine IV, University Heidelberg Hospital from 2012 to 2019. Written informed consent was obtained from each patient. Ethical approval was given by the Ethics Committee of University of Heidelberg. Results of $\mathrm{HH}$ patients were compared with 20 healthy control subjects. The study protocol was approved by the ethical committee of the University of Heidelberg. Patients serum samples were collected on a routine follow-up examination for $\mathrm{HbA1c}$, BMI, albumin, bilirubin, GGT, AST, ALT, prothrombin time (P), ferritin, transferrin, transferrin saturation (TS), iron, HFE-genotype, and I148M PNPLA3 polymorphism (rs738409/I148M) as well as serum lipids and lipoproteins including triglycerides, cholesterol, HDL, LDL and phospho- and sphingolipids. Patients with alcohol consumption $>20 \mathrm{~g} /$ day and statin therapy or any other lipid 
lowering therapy were excluded from the study. Ultrasound and evaluation for liver fibrosis using noninvasive method (Fibroscan) was performed by experienced medical doctors. The duration of experience was more than six months as a fulltime job in the department of sonography. Sonographic features to evaluate patients for hepatic steatosis were increased echogenicity of the background liver parenchyma, difference in echogenicity between the liver and right kidney, obscuration of the margins of the portal triads within the liver, and attenuation of the sound beam with diminished visualization of the deep right lobe. These criteria were used in the assessment of the presence and graduation of hepatic steatosis as normal, mild, moderate and severe. Diagnosis of $\mathrm{HH}$ was done by genetic analysis (C282Y) in the hospital central laboratory according to standard methods and determination of iron parameters (iron, ferritin, transferrin, TS). Patients with $\mathrm{HH}$ were treated by phlebotomy. The therapy was monitored by the determination of ferritin which should be less than $100 \mu \mathrm{g} / \mathrm{l}$.

\section{Lipidomic analysis}

Serum samples were subjected to lipid extraction according to Folch methods. The levels of phospho- and sphingolipids in lipid extracts were determined with a triple-quadrupole Micro Mass Quattro Premier mass spectrometer coupled with a liquid-chromatography system using the running conditions as previously described [36]. The following polar lipids (phospho- and sphingolipids) were measured: phosphatidylcholine (PC), lysophosphatidylcholine (LPC), phosphatidylinositol (PI), phosphatidylserine, phosphatidylethanolamine (PE), lysophosphatidylethanolamine (LPE), and sphingomyelin (SM). Serum polar lipids were quantified as $\mathrm{ng} / \mu \mathrm{l}$ serum.

\section{Statistical methods}

Variables were described by mean \pm standard deviation (SD) or median (interquartile range IQR) or frequencies, respectively. By means of detailed summary statistics and visual inspection of the distribution normality assumption was checked. Statistical differences in means between two groups (healthy vs. HH and CC vs. CG/ GG) were evaluated using Welch's t-test (due to unequal sample size homogeneity of variances cannot be assumed) or the nonparametric Mann-Whitney $U$ test in case normal distribution cannot be assumed. Statistical differences in proportions were assessed by chi-square test or Fisher's exact test in case of small expectancy counts. All analyses were performed with SPSS version 24 (IBM SPSS Statistic, Chicago, IL, USA). Two-sided $p$-values were interpreted descriptively and a p-value of $<0.05$ was considered statistically significant.

\section{Results}

Baseline characteristics of study population and stratified by low and high transferrin saturation

Patient characteristics are outlined in Table 1. A total of 54 subjects with $\mathrm{HH}$ were analyzed and compared with 20 healthy subjects. The two groups were significantly different in serum iron contents (Healthy subjects vs. $\mathrm{HH}$ : transferrin 2.1 vs. $1.8 \mathrm{~g} / \mathrm{l}, p<0.0001$, transferrin saturation $26.0 \%$ vs. $70.1 \%, p<0.0001$, iron $13.5 \mu \mathrm{mol} / \mathrm{l}$ vs. $31.8 \mu \mathrm{mol} / \mathrm{l}, p<0.0001$, ferritin $133.0 \mu / 1$ vs. $261.0 \mu / \mathrm{l}$, $p=0.02)$. Triglycerides $(74.0$ vs. $103.5 \mathrm{mg} / \mathrm{dl}, p=0.01$ ) were significantly higher in $\mathrm{HH}$ group. Cholesterol, HDL and LDL did not differ between the groups. GGT (12.5 $\mathrm{mg} / \mathrm{dl}$ vs. $23.0 \mathrm{mg} / \mathrm{dl}, p=0.001)$ and AST $(22.0 \mathrm{U} / \mathrm{l}$ vs. $29.0 \mathrm{U} / \mathrm{l}, p=0.01$ ) were in the normal range but significantly increased in HH group. Sonography of the liver showed that $29.6 \%$ of subjects with $\mathrm{HH}$ had normal liver without hepatic steatosis while 33.3, 22.2 and 9.3\% had mild, moderate and severe steatosis, respectively. Significant more hepatic steatosis in HH compared to the control group was found $(p<0.0001)$. Fibroscan measured liver stiffness of $6.7 \mathrm{kPa}( \pm 4.8 \mathrm{kPa})$ in $\mathrm{HH}$.

\section{Serum phospho- and sphingolipids of study population}

In addition to serum neutral lipids and lipoproteins, we also determined serum contents of polar lipids (phospho- and sphingolipids) in 53 subjects with $\mathrm{HH}$ which were compared with those of healthy control group (Table 2). A significant difference was observed for total $(p=0.005)$ and polyunsaturated fatty acids (PUFA, $p=$ $0.008)$ containing PE and total $(p=0.04)$ and monounsaturated fatty acids (MUFA, $p=0.01$ ) containing PI with higher values in subjects with $\mathrm{HH}$. No difference was observed for total, MUFA and PUFA containing PS between the two groups. In $\mathrm{HH}$ group, significant higher levels were observed PUFA containing LPE $(p=0.045)$. In LPC, a significant difference was seen in MUFA $(p=0.02)$ and PUFA $(p=0.004)$ containing LPC. No significance was reached for total and saturated LPC. Saturated $(p<0.0001)$, PUFA $(p=0.003)$, alkyl containing $(p=0.045)$ and total PC $(p=0.04)$ showed significant differences between the groups. Saturated $(p=0.03)$, total $(p=0.03)$ and MUFA $(p=0.045)$ containing SM were significantly elevated in $\mathrm{HH}$ group. $\mathrm{PC} / \mathrm{PE}$ ratio was clearly lower in $\mathrm{HH}$ group indicating a shift towards $\mathrm{PE}$ and therefore indicating a disturbance in PC metabolism.

\section{PNPLA3 genotype of study population}

54 subjects with $\mathrm{HH}$ were analyzed according to their I148M PNPLA3 polymorphism (rs738409). 48.2\% were wildtype (CC), $44.4 \%$ were heterozygous (CG) and $7.4 \%$ homozygous (GG) for the PNPLA3 polymorphism I148M (Table 1). Analysis of CC in comparison to CG/ 
Table 1 Clinical characteristics of study population. Mean \pm SD or median (IQR) or frequencies $n$ (\%) are shown with $p$-values for the group differences based on Welch's t-test (a), Mann-Whitney $U$ test (b), chi-square test (c) or Fisher's exact test (d)

\begin{tabular}{|c|c|c|c|c|}
\hline & Limits of normal & Healthy $n=20$ & $\mathrm{HH} n=54$ & $\boldsymbol{p}$-value \\
\hline gender (male) & & $11(55 \%)$ & $39(72.2 \%)$ & $0.98^{c}$ \\
\hline Age (years) & & $48.9 \pm 11.8$ & $51.3 \pm 15.0$ & $0.47^{\mathrm{a}}$ \\
\hline Type II diabetes mellitus & & $0(0 \%)$ & $6(11.1 \%)$ & $0.18^{d}$ \\
\hline BMI & $\mathrm{kg} / \mathrm{m}^{2}$ & $24.4 \pm 2.9$ & $26.0 \pm 3.4$ & $0.05^{\mathrm{a}}$ \\
\hline Cholesterol & $\mathrm{mg} / \mathrm{dl}$ & $186.6 \pm 35.5$ & $188.0 \pm 38.3$ & $0.89^{a}$ \\
\hline HDL & $>40 \mathrm{mg} / \mathrm{dl}$ & $60.0 \pm 17.3$ & $55.3 \pm 19.2$ & $0.34^{\mathrm{a}}$ \\
\hline LDL & $<160 \mathrm{mg} / \mathrm{dl}$ & $109.4 \pm 31.1$ & $111.7 \pm 26.8$ & $0.79^{\mathrm{a}}$ \\
\hline Triglycerides & $<150 \mathrm{mg} / \mathrm{dl}$ & $74.0(48.0)$ & $103.5(83.0)$ & $0.01^{\mathrm{b}}$ \\
\hline Albumin & $30-50 \mathrm{~g} / \mathrm{l}$ & $44.6 \pm 1.5$ & $44.8 \pm 2.6$ & $0.75^{\mathrm{a}}$ \\
\hline Bilirubin & $<1.0 \mathrm{mg} / \mathrm{dl}$ & $0.6(0.2)$ & $0.8(0.6)$ & $0.38^{\mathrm{b}}$ \\
\hline GGT & $<60 \mathrm{U} / \mathrm{l}$ & $12.5(18.5)$ & $23.0(30.3)$ & $0.001^{\mathrm{b}}$ \\
\hline AST & $<46 \mathrm{U} / \mathrm{l}$ & $22.0(14.0)$ & $29.0(19.5)$ & $0.01^{\mathrm{b}}$ \\
\hline ALT & $<50 \mathrm{U} / \mathrm{l}$ & $25.0(8.0)$ & $26.0(17.5)$ & $0.25^{\mathrm{b}}$ \\
\hline PT & $70-125 \%$ & $101.9 \pm 11.0$ & $98.6 \pm 16.2$ & $0.32^{a}$ \\
\hline Ferritin & $30-300 \mu \mathrm{g} / \mathrm{l}$ & $133.0(150.5)$ & $261.0(731.3)$ & $0.02^{\mathrm{b}}$ \\
\hline Transferrin & $2.0-3.6 \mathrm{~g} / \mathrm{l}$ & $2.1 \pm 0.3$ & $1.8 \pm 0.3$ & $<0.0001^{\mathrm{a}}$ \\
\hline TS & $16-45 \%$ & $26.0 \pm 9.6$ & $70.1 \pm 24.9$ & $<0.0001^{\mathrm{a}}$ \\
\hline Iron & $14-32 \mu \mathrm{mol} / \mathrm{l}$ & $13.5 \pm 4.7$ & $31.8 \pm 10.2$ & $<0.0001^{\circ}$ \\
\hline \multirow[t]{4}{*}{ Hepatic steatosis } & none & $18(90 \%)$ & $16(29.6 \%)$ & $<0.0001^{c}$ \\
\hline & mild & $0(0 \%)$ & $18(33.3 \%)$ & \\
\hline & moderate & $2(10 \%)$ & $12(22.2 \%)$ & \\
\hline & severe & $0(0 \%)$ & $5(9.3 \%)$ & \\
\hline FibroScan & $<6 \mathrm{kPa}$ & - & $6.7 \pm 4.8$ & - \\
\hline HFE-genotype & C282Y & - & 54 (100\%) & - \\
\hline \multirow[t]{3}{*}{ PNPLA3 genotype } & CC & - & $26(48.2 \%)$ & - \\
\hline & CG & - & $24(44.4 \%)$ & - \\
\hline & GG & - & $4(7.4 \%)$ & - \\
\hline
\end{tabular}

$A L T$ alanine aminotransferase; $A S T$ aspartate aminotransferase; $B M I$ body mass index; $H D L$ high-density lipoprotein; $H H$ hereditary hemochromatosis; $I Q R$ interquartile range; $L D L$ low-density lipoprotein; PNPLA3 human patatin like phospholipase domain-containing 3; PT prothrombin time; SD Standard deviation; TS transferrin saturation;

GG showed also no significant difference between the groups, especially in lipid (cholesterol, HDL, LDL, triglycerides) and iron parameters (transferrin, iron, TS, ferritin), grade of hepatic steatosis and fibrosis (Table 3). Phospho- and sphingolipids as well demonstrated no significant difference between these two groups (Table 4).

\section{Discussion}

In our study, we analyzed lipid metabolism and hepatic steatosis in $\mathrm{HH}$. This study is to our knowledge the first study in $\mathrm{HH}$ which investigated in addition to lipoproteins (HDL, LDL) and neutral lipids (cholesterol, triglycerides) phospho- and sphingolipid metabolism. Our results strengthen the hypothesis of altered lipid metabolism in $\mathrm{HH}$, especially in phospholipid metabolism and susceptibility to NAFLD and this was independent of PNPLA3 polymorphism.

It is known that hepatic steatosis is a cofactor in liver injury in $\mathrm{HH}$ [22], and $\mathrm{HH}$-dependent susceptibility to NAFLD is independent of BMI and triglyceride levels $[23,24]$. Clinical significant liver disease in $\mathrm{HH}$ is also associated with risk factors like heavy alcohol abuse and concomitant chronic liver diseases like chronic hepatitis C [37]. As HH subjects with high (> 20 g/day) alcohol consumption and concomitant chronic liver diseases were excluded from our study, it has to be assumed that these risk factors do not play a role in the observed alterations in our cohort.

In our cohort, BMI was as well not affected in $\mathrm{HH}$, and this indicates non-obese NAFLD in $\mathrm{HH}$ pathogenesis. However, our cohort shows that blood triglycerides 
Table 2 Phospho- and sphingolipids ( $\mathrm{ng} / \mu \mathrm{l}$ ) of study population. Serum samples were quantified in $\mathrm{ng} / \mu \mathrm{l}$ serum. Mean \pm SD or median (IQR) are shown with $p$-values for the group differences based on Welch's t-test (a) or Mann-Whitney $U$ test (b)

\begin{tabular}{|c|c|c|c|c|}
\hline & & Healthy $n=20$ & $\mathrm{HH} n=53$ & $\boldsymbol{p}$-value \\
\hline \multicolumn{5}{|c|}{ Phospholipids } \\
\hline \multirow[t]{5}{*}{ PC } & Saturated & $996.2 \pm 369.3$ & $750.6 \pm 30.6$ & $<0.0008^{\mathrm{a}}$ \\
\hline & MUFA & $2327.0 \pm 866.7$ & $2401.8 \pm 976.2$ & $0.75^{\mathrm{a}}$ \\
\hline & PUFA & $6163.9 \pm 2104.8$ & $8001.3 \pm 2334.6$ & $0.003^{\mathrm{a}}$ \\
\hline & Alkyl & $521.6 \pm 169.7$ & $619.3 \pm 203.1$ & $0.045^{\mathrm{a}}$ \\
\hline & Total & $10,008.8 \pm 3154.7$ & $11,773.0 \pm 3339.3$ & $0.04^{a}$ \\
\hline \multirow[t]{4}{*}{ LPC } & Saturated & $51.5 \pm 11.3$ & $56.9 \pm 14.6$ & $0.10^{\mathrm{a}}$ \\
\hline & MUFA & $12.5 \pm 3.4$ & $10.5 \pm 2.7$ & $0.02^{a}$ \\
\hline & PUFA & $19.6 \pm 4.2$ & $16.2 \pm 4.2$ & $0.004^{\mathrm{a}}$ \\
\hline & Total & $83.7 \pm 17.6$ & $83.6 \pm 19.7$ & $0.98^{\mathrm{a}}$ \\
\hline \multirow[t]{3}{*}{ PI } & MUFA & $14.4 \pm 6.5$ & $19.7 \pm 10.0$ & $0.01^{\mathrm{a}}$ \\
\hline & PUFA & $137.4 \pm 50.1$ & $165.0 \pm 61.0$ & $0.06^{\mathrm{a}}$ \\
\hline & Total & $152.1 \pm 55.7$ & $184.7 \pm 69.1$ & $0.04^{a}$ \\
\hline \multirow[t]{3}{*}{ PS } & MUFA & $0.4(2.6)$ & $0.0(4.0)$ & $0.71^{b}$ \\
\hline & PUFA & 17.7 (17.9) & 24.6 (52.0) & $0.15^{b}$ \\
\hline & Total & $18.4(18.3)$ & $26.5(59.5)$ & $0.18^{b}$ \\
\hline \multirow[t]{3}{*}{ PE } & MUFA & $75.2(55.4)$ & $91.9(329.7)$ & $0.05^{b}$ \\
\hline & PUFA & $198.6(103.5)$ & $289.2(257.0)$ & $0.005^{\mathrm{b}}$ \\
\hline & Total & $276.4(123.2)$ & $407.8(573.2)$ & $0.008^{b}$ \\
\hline \multirow[t]{4}{*}{ LPE } & Saturated & $1.2(0.9)$ & $1.3(0.8)$ & $0.87^{b}$ \\
\hline & MUFA & $0.5(0.4)$ & $0.5(0.9)$ & $0.95^{\mathrm{b}}$ \\
\hline & PUFA & $1.6(0.8)$ & $2.3(3.0)$ & $0.045^{b}$ \\
\hline & Total & $3.6(1.7)$ & $4.5(4.8)$ & $0.10^{\mathrm{b}}$ \\
\hline \multicolumn{5}{|c|}{ Sphingolipids } \\
\hline \multirow[t]{5}{*}{ SM } & Saturated & $711.3 \pm 271.3$ & $876.1 \pm 279.5$ & $0.03^{a}$ \\
\hline & MUFA & $2168.3 \pm 1339.6$ & $2879.7 \pm 1173.2$ & $0.045^{\mathrm{a}}$ \\
\hline & PUFA & $1537.9 \pm 517.6$ & $1728.4 \pm 380.7$ & $0.15^{\mathrm{a}}$ \\
\hline & Alkyl & $344.3 \pm 256.5$ & $465.4 \pm 236.7$ & $0.08^{a}$ \\
\hline & Total & $4761.8 \pm 2104.7$ & $5949.6 \pm 1743.3$ & $0.03^{a}$ \\
\hline \multicolumn{2}{|c|}{ Ratio PC/PE } & 34.7 & 22.2 & \\
\hline
\end{tabular}

$H H$ hereditary hemochromatosis; IQR interquartile range; $L P C$ lysophosphatidylcholine; $L P E$ lysophosphatidylethanoletamine; MUFA monounsaturated fatty acid; $P C$ phosphatidylcholine; PE phosphatidylethanolamine; PS phosphatidylserine; PUFA polyunsaturated fatty acid; SD standard deviation; SM sphingomyelin;

were significantly higher and hepatic steatosis was significantly more frequent in $\mathrm{HH}$ group. While the role of HFE polymorphism in the occurrence of NAFLD still remains unclear, our findings may suggest that ironoverload and subsequent oxidative stress in $\mathrm{HH}$ could be due to the alteration of hepatic triglyceride metabolism associated with hepatic steatosis. Accordingly, it is known that iron-overload increases serum triglycerides associated with fatty liver in experimental animals [38]. NAFLD patients also show an increase of both triglycerides and iron in the liver [39], and that iron stores as ferritin in NAFLD is associated with hypertriglyceridemia [40]. Iron overload can also affect visceral adipose tissue metabolism by a mechanism involving hepcidin upregulation [41]. In addition to NAFLD, hepatocellular iron deposition is associated with an increased risk of hepatic fibrosis [42] suggesting a critical role of iron in NAFLD progression to NASH. Taken together, increased blood triglycerides observed in our HH cohort is a pathologic marker of exaggerated hepatic steatosis caused by iron-overload. The alteration of adipose tissue metabolism by iron-overload could result in the lack of any increase of $\mathrm{BMI}$ in $\mathrm{HH}$, despite of increased hepatic steatosis.

Together with increased hepatic triglycerides, hepatic steatosis is associated with the depletion of liver 
Table 3 PNPLA3 genotype CC vs. CG/GG of hereditary hemochromatosis (HH) group. Mean \pm SD or median (IQR) or frequencies $n$ (\%) are shown with p-values for the group differences based on Welch's t-test (a), Mann-Whitney $U$ test (b) or chi-square test (c)

\begin{tabular}{|c|c|c|c|c|}
\hline & limits of normal & $C C n=26$ & $\mathrm{CG} / \mathrm{GG} n=28$ & $\overline{p \text {-value }}$ \\
\hline Cholesterol & $\mathrm{mg} / \mathrm{dl}$ & $181.6 \pm 35.2$ & $193.9 \pm 40.8$ & $0.26^{a}$ \\
\hline HDL & $>40 \mathrm{mg} / \mathrm{dl}$ & $58.8 \pm 20.4$ & $51.1 \pm 18.1$ & $0.18^{\mathrm{a}}$ \\
\hline LDL & $<160 \mathrm{mg} / \mathrm{dl}$ & $105.8 \pm 22.7$ & $116.3 \pm 29.3$ & $0.20^{\mathrm{a}}$ \\
\hline Triglycerides & $<150 \mathrm{mg} / \mathrm{dl}$ & $97.0(58.8)$ & $128.5(125.0)$ & $0.17^{\mathrm{b}}$ \\
\hline Ferritin & $\mu \mathrm{g} / \mathrm{l}$ & $153.5(465.5)$ & $562.0(1064.5)$ & $0.18^{\mathrm{b}}$ \\
\hline Transferrin & $2.0-3.6 \mathrm{~g} / \mathrm{l}$ & $1.9 \pm 0.3$ & $1.8 \pm 0.3$ & $0.40^{\mathrm{a}}$ \\
\hline TS & $16-45 \%$ & $73.8 \pm 22.8$ & $68.4 \pm 26.7$ & $0.44^{\mathrm{a}}$ \\
\hline Iron & $14-32 \mu \mathrm{mol} / \mathrm{l}$ & $33.1 \pm 9.2$ & $30.6 \pm 11.1$ & $0.34^{\mathrm{a}}$ \\
\hline Albumin & $30-50 \mathrm{~g} / \mathrm{l}$ & $44.7 \pm 2.7$ & $44.9 \pm 2.6$ & $0.79^{\mathrm{a}}$ \\
\hline Bilirubin & $<1.0 \mathrm{mg} / \mathrm{dl}$ & $0.6(0.5)$ & $0.8(0.7)$ & $0.20^{b}$ \\
\hline GGT & $<60 \mathrm{U} / \mathrm{l}$ & $23.0(39.5)$ & $26.0(25.3)$ & $0.94^{\mathrm{b}}$ \\
\hline AST & $<46 \mathrm{U} / \mathrm{l}$ & $25.0(15.0)$ & $35.5(20.3)$ & $0.04^{b}$ \\
\hline ALT & $<50 \mathrm{U} / \mathrm{l}$ & $23.5(10.5)$ & $31.5(16.5)$ & $0.19^{b}$ \\
\hline BMI & $\mathrm{kg} / \mathrm{m}^{2}$ & $26.4 \pm 3.9$ & $25.7 \pm 2.7$ & $0.44^{\mathrm{a}}$ \\
\hline FibroScan & $<6 \mathrm{kPa}$ & $6.8 \pm 5.4$ & $6.5 \pm 4.1$ & $0.79^{\mathrm{a}}$ \\
\hline \multirow[t]{4}{*}{ Hepatic steatosis } & none & $9(34.6 \%)$ & $7(25 \%)$ & \multirow[t]{4}{*}{$0.62^{c}$} \\
\hline & mild & $9(34.6 \%)$ & $9(32.1 \%)$ & \\
\hline & moderate & $4(15.4 \%)$ & $8(28.6 \%)$ & \\
\hline & severe & $3(3.8 \%)$ & $2(7.1 \%)$ & \\
\hline
\end{tabular}

$A L T$ alanine aminotransferase; $A S T$ aspartate aminotransferase; $B M I$ body mass index; $H D L$ high-density lipoprotein; $I Q R$ interquartile range; $L D L$ low-density lipoprotein; PNPLA3. human patatin like phospholipase domain-containing 3; SD standard deviation; TS transferrin saturation;

phospholipids including PC and PE in morbidly obese mice [43] and NAFLD patients [44]. Studies in PEMTdeficient mice have indicated that a decrease in hepatic $\mathrm{PC} / \mathrm{PE}$ ratio is linked to NAFLD [45], and variants of PEMT gene is associated with non-obese NAFLD [46]. $\mathrm{HH}$ subjects in our study had significantly higher serum PUFA-containing and total PE species and lower saturated-containing $\mathrm{PC}$ resulting in a decrease of $\mathrm{PC} /$ $\mathrm{PE}$ ratio. Thus, hepatic metabolism in steatotic $\mathrm{HH}$ may be dominated by a shift of metabolism towards $\mathrm{PE}$ as seen in PEMT-deficient mice [45] and non-obese NAFLD [46]. In support of our results, patients with NAFLD and NASH show higher hepatic PE and lower erythrocyte PC [47]. Furthermore, serum PE is shown to be significantly increased in NASH but not in NAFLD [48] Thus, a decrease of serum PC/PE ratio appears to be a hallmark biomarker of $\mathrm{HH}$ with iron-overload being critical in the progression to NASH [49]. While iron deficiency is reported to increase hepatic PC and PE in rats [50], conversely, iron-overload in $\mathrm{HH}$ liver may induce a decrease of PC and PE differently by an unknown mechanism. As liver X receptor (LXR) regulates PUFA metabolism in phospholipids [51] particularly PE [52], we speculate that LXR could be a target of iron-induced oxidative stress [53] that could lead to increased hepatic and serum PE in steatotic $\mathrm{HH}$.
While carriers of PNPLA3 polymorphism (rs738409/ I148M) are associated with hepatic steatosis and impaired lipid metabolism $[25,28-30,32]$ and hepatic steatosis was frequently seen in our $\mathrm{HH}$ cohort, we analyzed PNPLA3 polymorphism. In our cohort, PNPLA3 polymorphism did not show any significant alterations on iron and lipid metabolism parameters including lipoproteins (HDL, LDL), neutral lipids (cholesterol, triglycerides), phospho- and sphingolipid metabolism. In a recent study, the I148M variant in $\mathrm{HH}$ was also not associated with altered lipid levels, but with the presence of hepatic steatosis and severity of fibrosis and therefore maybe representing a potential factor for fibrosis progression [34]. In our cohort, no effect on grade of hepatic steatosis and fibrosis for risk allele $G$ was seen indicating that it does not have any impact on NAFLD pathophysiology in $\mathrm{HH}$. Hepatic steatosis in $\mathrm{HH}$ is therefore rather related to iron-overload and subsequent oxidative stress with impaired apolipoprotein B100 (ApoB100) and VLDL secretion $[9,10]$. Our study is to our knowledge the first study which investigated phospholipid metabolism in $\mathrm{HH}$ depending on PNPLA3 polymorphism. Our $\mathrm{HH}$ cohort revealed significantly lower serum PC and significantly higher serum PE when compared to healthy controls, but this was independent of PNPLA3 polymorphism suggesting that it does not 
Table 4 Phospho- and sphingolipids ( $\mathrm{ng} / \mu \mathrm{l})$ of hereditary hemochromatosis $(\mathrm{HH})$ group stratified by PNPLA3 genotype. Serum samples were quantified in $\mathrm{ng} / \mu \mathrm{l}$ serum. Mean \pm SD or median (IQR) are shown with p-values for the group differences based on Welch's t-test (a) or Mann-Whitney $U$ test (b)

\begin{tabular}{|c|c|c|c|c|}
\hline & & $C C n=26$ & $\mathrm{CG} / \mathrm{GG} n=28$ & $\overline{p \text {-value }}$ \\
\hline \multicolumn{5}{|l|}{ Phospholipids } \\
\hline \multirow[t]{5}{*}{ PC } & Saturated & $753.7 \pm 37.6$ & $747.8 \pm 23.0$ & $0.50^{\mathrm{a}}$ \\
\hline & MUFA & $2524.5 \pm 1078.8$ & $2292.3 \pm 880.0$ & $0.40^{\mathrm{a}}$ \\
\hline & PUFA & $8352.12 \pm 467.5$ & $7688.1 \pm 2206.7$ & $0.31^{a}$ \\
\hline & Alkyl & $619.1 \pm 204.9$ & $619.4 \pm 205.3$ & $0.99^{\mathrm{a}}$ \\
\hline & Total & $12,249.3 \pm 3624.0$ & $11,347.7 \pm 3066.5$ & $0.34^{\mathrm{a}}$ \\
\hline \multirow[t]{4}{*}{ LPC } & Saturated & $54.0 \pm 12.4$ & $59.5 \pm 16.0$ & $0.17^{\mathrm{a}}$ \\
\hline & MUFA & $10.2 \pm 2.5$ & $10.8 \pm 2.9$ & $0.44^{\mathrm{a}}$ \\
\hline & PUFA & $15.8 \pm 4.0$ & $16.6 \pm 4.5$ & $0.52^{\mathrm{a}}$ \\
\hline & Total & $80.0 \pm 16.5$ & $86.8 \pm 21.9$ & $0.21^{\mathrm{a}}$ \\
\hline \multirow[t]{3}{*}{ PI } & MUFA & $18.80 \pm 9.5$ & $20.5 \pm 10.5$ & $0.55^{\mathrm{a}}$ \\
\hline & PUFA & $155.1 \pm 57.6$ & $173.9 \pm 63.7$ & $0.26^{a}$ \\
\hline & Total & $173.9 \pm 64.9$ & $194.3 \pm 72.4$ & $0.28^{\mathrm{a}}$ \\
\hline \multirow[t]{3}{*}{ PS } & MUFA & $3.2(5.1)$ & $0.0(2.6)$ & $0.16^{\mathrm{b}}$ \\
\hline & PUFA & $24.6(98.3)$ & $23.4(39.4)$ & $0.55^{\mathrm{b}}$ \\
\hline & Total & $27.2(104.1)$ & $23.6(49.9)$ & $0.43^{b}$ \\
\hline \multirow[t]{3}{*}{ PE } & MUFA & $85.7(363.4)$ & $92.8(271.3)$ & $0.99^{b}$ \\
\hline & PUFA & $279.1(236.7)$ & 302.5 (278.7) & $0.48^{b}$ \\
\hline & total & $370.9(607.0)$ & $409.1(545.4)$ & $0.64^{b}$ \\
\hline \multirow[t]{4}{*}{ LPE } & Saturated & $1.3(0.8)$ & $1.3(0.8)$ & $0.94^{\mathrm{b}}$ \\
\hline & MUFA & $0.4(1.1)$ & $0.6(0.9)$ & $0.46^{b}$ \\
\hline & PUFA & $2.4(4.7)$ & $2.2(2.5)$ & $0.76^{\mathrm{b}}$ \\
\hline & Total & $3.9(5.1)$ & $4.6(4.5)$ & $0.78^{b}$ \\
\hline \multicolumn{5}{|l|}{ Sphingolipids } \\
\hline \multirow[t]{5}{*}{ SM } & Saturated & $892.4 \pm 269.5$ & $861.6 \pm 292.2$ & $0.69^{a}$ \\
\hline & MUFA & $3074.6 \pm 1122.1$ & $2705.7 \pm 1210.4$ & $0.26^{\mathrm{a}}$ \\
\hline & PUFA & $1702.8 \pm 409.3$ & $1751.3 \pm 359.3$ & $0.65^{a}$ \\
\hline & Alkyl & $461.2 \pm 228.5$ & $469.10 \pm 248.0$ & $0.90^{\mathrm{a}}$ \\
\hline & Total & $6130.94 \pm 1688.2$ & $5787.7 \pm 1806.0$ & $0.48^{a}$ \\
\hline Ratio PC/PE & & 23.1 & 21.4 & \\
\hline
\end{tabular}

$H H$ hereditary hemochromatosis; $I Q R$ interquartile range; $L P C$ lysophosphatidylcholine; $L P E$ lysophosphatidylethanoletamine; $P C$ phosphatidylcholine; $P E$ phosphatidylethanolamine; $P S$ phosphatidylserine; $S D$ standard deviation; SM sphingomyelin;

have any effect on altered phospholipid metabolism in $\mathrm{HH}$.

Limitations of our study are a small cohort size. For further investigations, it is important to analyze liver lipidome, measure VLDL secretion and phospholipid profiles of VLDL of $\mathrm{HH}$ patients to clarify the role of altered VLDL secretion and composition in pathogenesis of susceptibility to NAFLD in $\mathrm{HH}$.

\section{Conclusion}

Our study supports the hypothesis of altered lipid metabolism and susceptibility to NAFLD in HH. Disturbed phospholipid metabolism is likely an important factor in pathogenesis of hepatic steatosis in $\mathrm{HH}$.

\section{Abbreviations \\ ALT: Alanine aminotransferase; ApoB100: Apolipoprotein B100; AST: Aspartate aminotransferase; BMI: Body mass index; FFA: Free fatty acids; FP- \\ 1: Ferroportin-1; GGT: Gamma-glutamyltransferase; HH: Hereditary hemochromatosis; HDL: High-density lipoprotein; LCPUFA: Long-chain polyunsaturated fatty acids; LDL: Low-density lipoprotein; \\ LPC: Lysophosphatidylcholine; LPE: Lysophosphatidylethanolamine; LXR: Liver $X$ receptor; MUFA: Monounsaturated fatty acid; NAFLD: Non-alcoholic fatty liver disease; NASH: Non-alcoholic steatohepatitis; PC: Phosphatidylcholine; PE: Phosphatidylethanolamine; PEMT: Phosphatidylethanolamine N- methyltransferase; PI: Phosphatidylinositol; PNPLA3: Human patatin like phospholipase domain-containing 3; PS: Phosphatidylserine; PT: Prothrombin time; PUFA: Polyunsaturated fatty acid; SM: Sphingomyelin; TS: Transferrin saturation; VLDL: Very-low density lipoprotein}

\section{Acknowledgments}

J.S. was a recipient of Rahel Goitein Straus award from Medical Faculty of University of Heidelberg. We thank Petra Klöters-Plachky for technical assistance.

\section{Authors' contributions}

UM, WS, JS were involved in study concept and design, acquisition of data analysis, interpretation of data and statistical analysis. MK was involved in interpretation of data and statistical analysis. UM, WC, JS were involved in drafting of manuscript, study supervision, revision of manuscript for intellectual content. HGS carried out liquid-chromatography measurement and analyses. All authors read and approved final version of manuscript.

\section{Funding}

None.

Availability of data and materials

The dataset used and analyzed during the current study is available from the corresponding author on reasonable request.

\section{Ethics approval and consent to participate}

Ethical approval for this prospective, observational single center study was given by the Ethics Committee of University of Heidelberg. Written informed consent was obtained from each patient at study inclusion.

\section{Consent for publication}

Not applicable.

\section{Competing interests}

The authors declare that they have no competing interests.

\section{Author details}

${ }^{1}$ Department of Gastroenterology, University Hospital Heidelberg, Im Neuenheimer Feld 410, 69120 Heidelberg, Germany. ${ }^{2}$ Institute of Medical Biometry and Informatics, University Hospital Heidelberg, Heidelberg, Germany.

Received: 28 December 2019 Accepted: 22 April 2020

Published online: 17 July 2020

\section{References}

1. Allen KJ, Gurrin LC, Constantine CC, Osborne NJ, Delatycki MB, Nicoll AJ, et al. Iron-overload-related disease in HFE hereditary hemochromatosis. N Engl J Med. 2008;358:221-30.

2. Adams PC, Reboussin DM, Barton JC, McLaren CE, Eckfeldt JH, McLaren GD, et al. Hemochromatosis and Iron overload screening (HEIRS) study research investigators. Hemochromatosis and iron-overload screening in a racially diverse population. N Engl J Med. 2005;352:1769-78. 
3. Bloomer SA, Brown KE. Iron-induced liver injury: a critical reappraisal. Int J Mol Sci. 2019;20:2132.

4. Fleming RE, Ponka PN. Iron overload in human disease. Engl J Med. 2012; 366((4):348-59.

5. Ahmed U, Latham PS, Oates PS. Interactions between hepatic iron and lipid metabolism with possible relevance to steatohepatitis. World J

Gastroenterol. 2012;18(34):4651-8.

6. Brunet S, Thibault L, Delvin E, Yotov W, Bendayan M, Levy E. Dietary iron overload and induced lipid peroxidation are associated with impaired plasma lipid transport and hepatic sterol metabolism in rats. Hepatology. 1999;29(6):1809-17.

7. Graham RM, Chua AC, Carter KW, Delima RD, Johnstone D, Herbison CE, et al. Hepatic iron loading in mice increases cholesterol biosynthesis. Hepatology. 2010;52(2):462-71.

8. Choi JS, Koh IU, Lee HJ, Kim WH, Song J. Effects of excess dietary iron and fat on glucose and lipid metabolism. J Nutr Biochem. 2013;24(9):1634-44.

9. Barisani D, Meneveri R, Ginelli E, Cassani C, Conte D. Iron overload and gene expression in HepG2 cells: analysis by differential display. FEBS Lett. 2000; 469(2-3):208-12

10. Pankow JS, Boerwinkle E, Adams PC, Guallar E, Leiendecker-Foster C, Rogowski J, et al. HFE C282Y homozygotes have reduced low-density lipoprotein cholesterol: the Atherosclerosis Risk in Communities (ARIC) Study. Transl Res. 2008;152(1):3-10.

11. Cabrita M, Pereira CF, Rodrigues P, Cardoso EM, Arosa FA. Altered expression of CD1d molecules and lipid accumulation in the human hepatoma cell line HepG2 after iron loading FEBS J. 2005;272(1):152-165. https://doi.org/https://doi.org/10.1111/j.1432-1033.2004.04387.x.

12. Du Plooy JN, Bester J, Pretorius E. Eryptosis in Haemochromatosis: implications for rheology. Clin Hemorheol Microcirc. 2018;69(4):457-69.

13. Stechemesser L, Eder SK, Wagner A, Patsch W, Feldman A, Strasser M, et al. Metabolomic profiling identifies potential pathways involved in the interaction of iron homeostasis with glucose metabolism. Mol Metab. 2016; 6(1):38-47.

14. Noga AA, Vance DE. A gender-specific role for phosphatidylethanolamine $\mathrm{N}$-methyltransferase-derived phosphatidylcholine in the regulation of plasma high density and very low density lipoproteins in mice. J Biol Chem. 2003;278(24):21851-9.

15. Jacobs RL, Devlin C, Tabas I, Vance DE. Targeted deletion of hepatic CTP: phosphocholine cytidylyltransferase alpha in mice decreases plasma high density and very low density lipoproteins. J Biol Chem. 2004;279:47402-10.

16. Valenzuela R, Rincón-Cervera MÁ, Echeverría F, Barrera C, Espinosa A, Hernández-Rodas MC, et al. Iron-induced pro-oxidant and pro-lipogenic responses in relation to impaired synthesis and accretion of long-chain polyunsaturated fatty acids in rat hepatic and extrahepatic tissues. Nutrition. 2018;45:49-58

17. Mateo-Gallego R, Calmarza P, Jarauta E, Burillo E, Cenarro A, Civeira F. Serum ferritin is a major determinant of lipid phenotype in familial combined hyperlipidemia and familial hypertriglyceridemia. Metabolism. 2010;59(2): 154-8.

18. Solanas-Barca M, Mateo-Gallego R, Calmarza P, Jarauta E, Bea AM, Cenarro A, et al. Mutations in HFE causing hemochromatosis are associated with primary hypertriglyceridemia. J Clin Endocrinol Metab. 2009;94(11):4391-7.

19. Casanova-Esteban P, Guiral N, Andrés E, Gonzalvo C, Mateo-Gallego R, Giraldo $P$, et al. Effect of phlebotomy on lipid metabolism in subjects with hereditary hemochromatosis. Metabolism. 2011;60(6):830-4

20. Mateo-Gallego R, Lacalle L, Pérez-Calahorra S, Marco-Benedí V, Recasens V, Padrón N, et al. Efficacy of repeated phlebotomies in hypertriglyceridemia and iron overload: a prospective, randomized, controlled trial. J Clin Lipidol. 2018:12(5):1190-8.

21. Cash WJ, O'Neill S, O'Donnell ME, McCance DR, Young IS, McEneny J, et al. Endothelial function, antioxidant status and vascular compliance in newly diagnosed HFE C282Y homozygotes. Adv Med Sci. 2014;59(1):28-33.

22. Powell EE, Ali A, Clouston AD, Dixon JL, Lincoln DJ, Purdie DM, et al. Steatosis is a cofactor in liver injury in hemochromatosis. Gastroenterology. 2005;129:1937-43.

23. Valenti L, Dongiovanni P, Fracanzani AL, Santorelli G, Fatta E, Bertelli C, Taioli E, Fiorelli G, Fargion S. Increased susceptibility to nonalcoholic fatty liver disease in heterozygotes for the mutation responsible for hereditary hemochromatosis. Dig Liver Dis. 2003;35:172-8.

24. Ye Q, Qian BX, Yin WL, Wang FM, Han T. Association between the HFE C282Y, H63D polymorphisms and the risks of non-alcoholic fatty liver disease, liver cirrhosis and hepatocellular carcinoma: an updated systematic review and meta-analysis of 5,758 cases and 14,741 controls. PLoS One. 2016;11(9):e0163423.

25. Kienesberger PC, Oberer M, Lass A, Zechner R. Mammalian patatin domain containing proteins: a family with diverse lipolytic activities involved in multiple biological functions. J Lipid Res. 2009;50(Suppl):S63-8.

26. Romeo S, Kozlitina J, Xing C, Pertsemlidis A, Cox D, Pennacchio LA, et al. Genetic variation in PNPLA3 confers susceptibility to nonalcoholic fatty liver disease. Nat Genet 2008;40:1461-1465. https://doi.org/https://doi.org/10. 1038/ng.257.

27. Eslam M, Valenti L, Romeo S. Genetics and epigenetics of NAFLD and NASH: clinical impact. J Hepatol. 2018;68(2):268-79.

28. Pingitore P, Pirazzi C, Mancina RM, Motta BM, Indiveri C, Pujia A, Montalcini T, Hedfalk K, Romeo S. Recombinant PNPLA3 protein shows triglyceride hydrolase activity and its $1148 \mathrm{M}$ mutation results in loss of function. Biochim Biophys Acta. 2014;1841(4):574-80.

29. Sookoian S, Pirola CJ. Meta-analysis of the influence of I148M variant of patatin-like phospholipase domain containing 3 gene (PNPLA3) on the susceptibility and histological severity of nonalcoholic fatty liver disease. Hepatology. 2011;53:1883-94.

30. He S, McPhaul C, Li JZ, Garuti R, Kinch L, Grishin NV, et al. A sequence variation (1148M) in PNPLA3 associated with nonalcoholic fatty liver disease disrupts triglyceride hydrolysis. J Biol Chem. 2010;285(9):6706-15.

31. Pirazzi C, Adiels M, Burza MA, Mancina RM, Levin M, Ståhlman M, et al. Patatin-like phospholipase domaincontaining 3 (PNPLA3) I148M (rs7,38,409) affects hepatic VLDL secretion in humans and in vitro. J Hepatol. 2012;57(6): 1276-82.

32. Ruhanen $H$, Perttilä J, Hölttä-Vuori $M$, Zhou $Y$, Yki-Järvinen $H$, Ikonen $E_{i}$ Käkelä R, Olkkonen VM. PNPLA3 mediates hepatocyte triacylglycerol remodeling. J Lipid Res. 2014;55(4):739-46.

33. Karamfilova V, Gateva A, Assyov Y, Alexiev A, Savov A, Yaneva N, Ivanova I, Ivanova-Boyanova R, Ivanova R, Vlahova Z, Mateva L, Kamenov Z. PNPLA3 $1148 \mathrm{M}$ polymorphism in patients with nonalcoholic fatty liver disease, obesity and Prediabetes. J Gastrointestin Liver Dis. 2019;28(4):433-8.

34. Speliotes EK, Butler JL, Palmer CD, Voight BF, Hirschhorn JN. PNPLA3 variants specifically confer increased risk for histologic nonalcoholic fatty liver disease but not metabolic disease. Hepatology. 2010;52:904-12.

35. Valenti L, Maggioni P, Piperno A, Rametta R, Pelucchi S, Mariani R, Dongiovanni P, Fracanzani AL, Fargion S. Patatin-like phospholipase domain containing-3 gene $1148 \mathrm{M}$ polymorphism, steatosis, and liver damage in hereditary hemochromatosis. World J Gastroenterol. 2012;18(22):2813-20.

36. Jiao L, Gan-Schreier H, Zhu X, Wei W, Tuma-Kellner S, Liebisch G, et al. Ageing sensitized by iPLA2 $\beta$ deficiency induces liver fibrosis and intestinal atrophy involving suppression of homeostatic genes and alteration of intestinal lipids and bile acids. Biochim Biophys Acta. 2017;1862(12):1520-33.

37. Sanchez-Luna SA, Brown KE. Clinical Burden of Liver Disease From Hemochromatosis at an Academic Medical Center. Hepatol Commun. 2017; 1(5):453-9.

38. Silva M, Silva ME, de Paula $H_{1}$ Carneiro CM, Pedrosa ML. Iron overload alters glucose homeostasis, causes liver steatosis, and increases serum triacylglycerols in rats. Nutr Res. 2008;28(6):391-8.

39. Martin-Rodriguez JL, Gonzalez-Cantero J, Gonzalez-Cantero A, MartíBonmatí L, Alberich-Bayarri Á, Gonzalez-Cejudo T, Gonzalez-Calvin JL. Insulin resistance and NAFLD: relationship with intrahepatic iron and serum TNF-a using 1H MR spectroscopy and MRI. Diabetes Metab. 2019;45(5):473-9.

40. Suárez-Ortegón MF, Ensaldo-Carrasco E, Shi T, McLachlan S, Fernández-Real JM, Wild SH. Ferritin, metabolic syndrome and its components: a systematic review and meta-analysis. Atherosclerosis. 2018;275:97-106.

41. Dongiovanni P, Ruscica M, Rametta R, Recalcati S, Steffani L, Gatti S, Girelli D, Cairo G, Magni P, Fargion S, Valenti L. Dietary iron overload induces visceral adipose tissue insulin resistance. Am J Pathol. 2013;182(6):2254-63.

42. O'Brien J, Powell LW. Non-alcoholic fatty liver disease: is iron relevant? Hepatol Int. 2012;6(1):332-41.

43. Deng $X$, Wang J, Jiao L, Utaipan T, Tuma-Kellner S, Schmitz G, Liebisch G, Stremmel W, Chamulitrat W. IPLA2 $\beta$ deficiency attenuates obesity and hepatic steatosis in Ob/Ob mice through hepatic fatty-acyl phospholipid remodeling. Biochim Biophys Acta. 2016;1861(5):449-61.

44. Puri P, Baillie RA, Wiest MM, Mirshahi F, Choudhury J, Cheung O, et al. A lipidomic analysis of nonalcoholic fatty liver disease. Hepatology. 2007:46(4): 1081-90. 
45. Li Z, Agellon LB, Allen TM, Umeda M, Jewell L, Mason A, Vance DE. The ratio of phosphatidylcholine to phosphatidylethanolamine influences membrane integrity and steatohepatitis. Cell Metab. 2006;3:321-31.

46. Bale G, Vishnubhotla RV, Mitnala S, Sharma M, Padaki RN, Pawar SC, Durvur RN. Whole-exome sequencing identifies a variant in Phosphatidylethanolamine $\mathrm{N}$-methyltransferase gene to be associated with lean-nonalcoholic fatty liver disease. J Clin Exp Hepatol. 2019;9(5):561-8.

47. Arendt BM, Ma DW, Simons B, Noureldin SA, Therapondos G, Guindi M, Sherman M, Allard JP. Nonalcoholic fatty liver disease is associated with lower hepatic and erythrocyte ratios of phosphatidylcholine to phosphatidylethanolamine. Appl Physiol Nutr Metab. 2013;38(3):334-40.

48. Ma DW, Arendt BM, Hillyer LM, Fung SK, McGilvray I, Guindi M, Allard JP. Plasma phospholipids and fatty acid composition differ between liver biopsy-proven nonalcoholic fatty liver disease and healthy subjects. Nut Diabetes. 2016;6(7)::220

49. Tsurusaki S, Tsuchiya Y, Koumura T, Nakasone M, Sakamoto T, Matsuoka M, Imai H, Yuet-Yin Kok C, Okochi H, Nakano H, Miyajima A, Tanaka M. Hepatic ferroptosis plays an important role as the trigger for initiating inflammation in nonalcoholic steatohepatitis. Cell Death Dis. 2019;10(6):449.

50. Stangl Gl, Kirchgessner M. Different degrees of moderate iron deficiency modulate lipid metabolism of rats. Lipids. 1998;33(9):889-95.

51. Jalil A, Bourgeois T, Ménégaut L, Lagrost L, Thomas C, Masson D. Revisiting the Role of LXRs in PUFA Metabolism and Phospholipid Homeostasis. Int J Mol Sci. 2019;20(15):pii: E3787.

52. Santinha D, Klopot A, Marques I, Ellis E, Jorns C, Johansson H, Melo T, Antonson P, Jakobsson T, Félix V, Gustafsson J̊̊, Domingues MR, Mode A, Helguero LA. Lipidomic analysis of human primary hepatocytes following LXR activation with GW3965 identifies AGXT2L1 as a main target associated to changes in phosphatidylethanolamine. J Steroid Biochem Mol Biol. 2019; 198:105558.

53. Alba G, Reyes ME, Santa-María C, Ramírez R, Geniz I, Jiménez J, Martín-Nieto $J$, Pintado $E$, Sobrino $F$. Transcription of liver $X$ receptor is down-regulated by 15 -deoxy- $\Delta(12,14)$-prostaglandin $J(2)$ through oxidative stress in human neutrophils. PLoS One. 2012;7(10):e42195.

\section{Publisher's Note}

Springer Nature remains neutral with regard to jurisdictional claims in published maps and institutional affiliations.

Ready to submit your research? Choose BMC and benefit from:

- fast, convenient online submission

- thorough peer review by experienced researchers in your field

- rapid publication on acceptance

- support for research data, including large and complex data types

- gold Open Access which fosters wider collaboration and increased citations

- maximum visibility for your research: over $100 \mathrm{M}$ website views per year

At $\mathrm{BMC}$, research is always in progress.

Learn more biomedcentral.com/submissions 